Inquiries After Homicide (Peay, 1996). The work reviewed here reports on an empirical study of the decision-making processes engaged in by psychiatrists (often in their responsible medical officer capacity), approved social workers and Second Opinion Appointed Doctors (SOADs) in connection with the admission, treatment, detention and discharge of detained patients under the Mental Health Act 1983

A short review cannot do justice to the rich (and sometimes disquieting) material contained in Peay's careful critical analysis. Her 'subjects' consisted of 106 participants; 52 psychiatrists from the Faculty of General and Community Psychiatry Division of the College, 14 SOADs and 40 approved social workers. 'The study examined whether, given identical case materials, individual and paired decisionmakers reached similar decisions about the application or non-application of the law, and, more critically, whatever the nature of the decisions made, how these decisions were justified by the parties making them' (p.x). Peay's intention (having stated 'that this is an odd book... having neither the methodological rigour of a research report, nor the analytical rigour of a scholarly text)' was to attempt to recapture the sense of 'anxiety, excitement, curiosity and discovery experienced by those participating in the research' (p. xi).

Three 'manufactured' cases and accompanying videos formed the basis of the research material. These concerned $\mathrm{Mr}$ Draper, 'A Case For Admission'; Mr Wright, 'A Case For Discharge'; and Hazel Robinson, 'A Case For Compulsory Treatment'. The manner in which the mental health professionals in her sample reached their decisions is described in meticulous and fascinating detail. Significantly, one of the major findings concerned the confusion demonstrated by a number of the professionals about the correct application of the law. Another major finding was the role played by what Peay describes as a 'cautionary' approach to decision-making. Perhaps one of the most important points made by Peay in her concluding chapter is that 'the research findings should not be judged merely by the nature of the decisions made, but, as importantly, if not more importantly by the reasons the practitioners gave for these decisions'. In her Foreword to the book, Lady Justice Hale (who will be known to many readers in her former academic role as Brenda Hoggett), describes the book as 'fascinating', a statement which I echo wholeheartedly. I think this book is a 'must' for all who are thoughtful about the compulsory powers afforded in the current mental health legislation.

PEAY, J. (1989) Tribunals onTrial: A Study of DecisionMaking Under the Mental Health Act 1983. London: Clarendon Press.

PEAY, J. (ed.) (1996) Inquiries after Homicide. London: Gerald Duckworth.

Herschel Prins University of Loughborough

\title{
miscellany
}

\section{Research study: Felix Post}

The Wellcome Trust has granted Dr Claire Hilton a short-term Research Leave award in the History of Medicine to research 'Felix Post (1913-2001) - a biographical study'. Dr Hilton would be most interested to hear from anyone who has memories of Felix Post, who may have known him in his early life in Berlin, as a medical student at Bart's, interned on the Isle of Man, as a doctor in the Army, or at any later stages of his career in psychiatry, especially in Edinburgh in the 1940s or at the Maudsley Hospital from 1947-1978. Dr Hilton can be contacted by phone until 31 October 2004 on 07976768542 or
0208959 6063; by e-mail

(claire.hilton@nhs.net) or by post: Mental Health Service for Older Adults, Mental Health Centre, Northwick Park Hospital, Watford Road, Harrow HA1 3UJ.

\section{Second Opinion Appointed Doctors: Mental Health Act Commission}

The Mental Health Act Commission (MHAC) is responsible for the appointment of doctors to undertake the Second Opinions under the powers of Part IV of the Mental Health Act 1983. The Commission invites consultant psychiatrists of at least 5 years' standing to apply for appointment to its panel of available doctors. There has recently been a significant increase in fees payable to Second Opinion Appointed Doctors. The Commission is particularly looking for doctors in Cumbria; Morecambe Bay; Lancashire; Wales; Gloucestershire; Hampshire; Surrey; Sussex; Kent; Suffolk; and Norfolk. Application forms are available on the Commission's website (www.mhac.trent.nhs.uk) or from the Commission's Office. Applications should be sent to Paramjit Thamu, MHAC, Maid Marian House, 56 Hounds Gate, Nottingham NG1 6BG (e-mail thamup@mhac.trent.nhs.uk; tel 0115943 7100 ext. 158)

\section{forthcoming events}

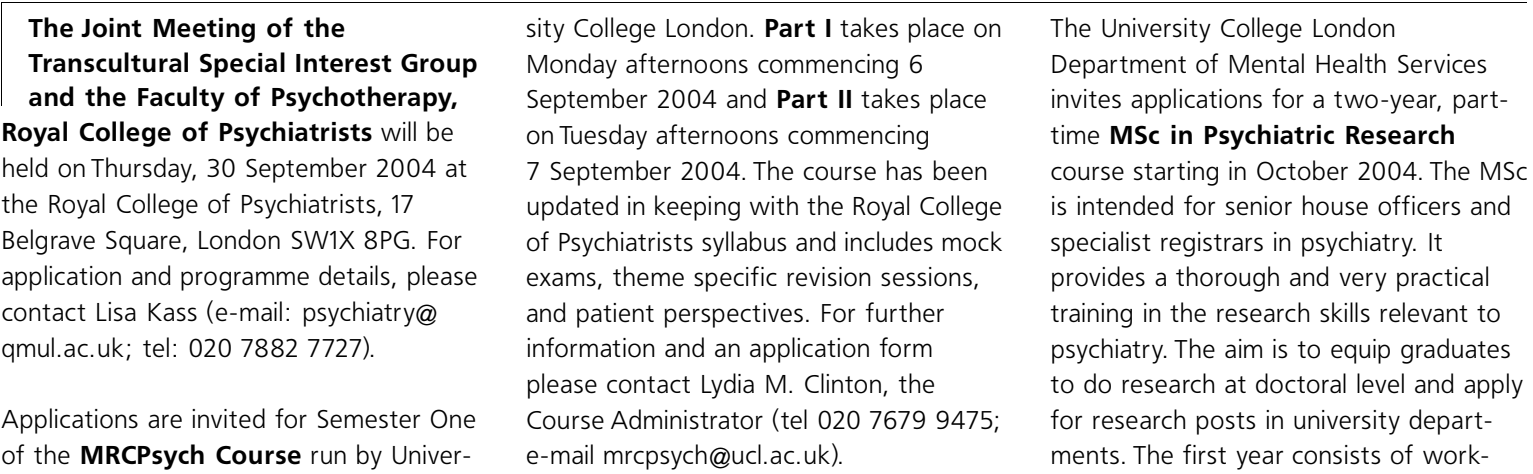


shops and seminars on research skills, held on Monday afternoons. In the second year students undertake a research project under supervision and submit a dissertation. Early application is advisable as places are limited. For an application form and prospectus please contact Lydia M. Clinton, the Course Administrator (tel: 0207679 475; e-mail: mrcpsych@ucl.ac.uk). To discuss the course please contact the Course Tutor, Dr Sonia Johnson (e-mail: s.johnson@ ucl.ac.uk).
Milton Keynes Primary Care Trust would like to announce the following one-day Psychotherapy Seminar: Asperger's Syndrome in Adult Patients. This will be held at the Milton Keynes Post Graduate Medical Centre on Friday, 24 September 2004 from 9 am to 4.30 pm. The seminar is aimed at psychiatrists, members of Community Mental Health Teams, general practitioners, counsellors, nurses and social workers. It is relevant to all those who wish to know more about Asperger's syndrome (AS) diagnosis, treatment and how it affects the life experience of people with AS and their presentation in mental health services. The workshop will give insight by looking into AS and its difficulties and treatment. For further information please contact Jane Gurnett, Secretary, Psychotherapy Department, Campbell Centre, Milton Keynes PCT (e-mail: Gurnett.Jane@ mkc-tr.anglox.nhs.uk; tel: 01908243134 fax 01908231 948). 